\title{
An Interview with Thomas Conway
}

\author{
Rosana Herrero-Martín
}

Instituto Cervantes, Bremen (Germany)

Copyright (c) 2009 by Rosana Herrero-Martín. This text may be archived and redistributed both in electronic form and in hard copy, provided that the author and journal are properly cited and no fee is charged for access.

\begin{abstract}
Thomas Conway is Literary Manager of the Druid Theatre Company (Galway), independent director and lecturer of Contemporary Theatre in the National University of Ireland, Galway. He was born in Sydney but his family moved to Ireland when he was 5 years old. He attended University College Cork and studied English including theatre, and history. He has been working in the professional theatre since graduating, primarily as a director of new and classic work, but also as playwright and literary manager.
\end{abstract}

Thomas Conway es director literario de la Druid Theatre Company de Galway, director teatral independiente y profesor de Teatro Contemporáneo en la National University of Ireland de Galway. Nació en Sydney, pero a los cinco años la familia se trasladó a Irlanda. Desde que terminó sus estudios de literatura inglesa e historia en University College Cork, se ha dedicado al teatro profesional, principalmente como director de piezas clásicas y nuevas, pero también como dramaturgo y director literario.

Q: You have just come back from the DruidSynge USA tour. What impressions about the American reception of the plays The Playboy of the Western World and The Shadow of the Glen do you bring back home? Were the productions much different from the original DruidSynge project in 2005?

A: Having rehearsed with an entirely new cast in Dublin, we previewed this production in the University of Illinois. With the first performance we discovered that the dialogue was often too difficult for the American audience to understand, especially given the way the actors were delivering it (even though we'd supplied a glossary in the programme). The accent combined with the language was simply too inaccessible for that American audience. So we reviewed the script phrase by phrase and while we didn't change a word in it, the actors did make adjustments in respect of its pronunciation and physical embodiment. Attuning the production to a US audience became our biggest challenge, one we took on directly and could never be complacent about. I think we succeeded but the scale of the challenge was considerable and was certainly new to me.

Q: You are Literary Manager at the Druid, though you have also been assistant director to Garry Hynes in various Druid productions. Could you tell us about your work?

A: A literary manager is responsible for advising the artistic director in relation to programming. For instance, the LM is the point of contact for all new plays that come into the company, and has a responsibility to find new work for production, however it might be found. The LM needs to be open to all 
possibilities for doing this - there is no formula as such. In relation to the new work we've done in my time - at least ten new plays (productions and readings) -, no pattern connects them, it is always a charmed route that sees the play arrive with us. Some plays have come in through from the open submissions process, some from commissions, some from inviting the writer to consider Druid with their new play, some owing to relationships that go back a number of years, some to chance meetings. I combine interaction with writers with an exploration and research on classics (Irish and International) and try to ensure that the company is empowered to make the best decisions on its programming, in rehearsals and in the promoting and setting the context for the plays.

Q: How does a theatre director make up his $\mathrm{CV}$ in Ireland: education, training, practical experience?

A: Professional training of a specialist kind does not exist for theatre directors in Ireland but the opportunity to get hands on experience in the various fields exists in abundance for those who are committed. Mostly you need either to present? yourself as an assistant director or go abroad for training opportunities. In their early years in theatre most people start up their own company and progress by initiative, determination and the good will shown by others.

Q: BIG QUESTION. From script to stage. Tell us about the workings and the timing of a theatre director's operative mind during this process.

A: It needs to be simple before it is complex and so the work needs to be grounded in a vision. Or at least I've always started with a vision, something that has me in its grip, and if bereft of a vision would not direct a play. I also admit to myself throughout that we don't know the play, we have to find the play, and that everyone working on it must set out to discover it - a never-ending discovery. I become insatiable to begin the journey with the creative team, actors, designers, everybody. I'm also determined to surprise the play, work against its grain, shock it out of its sense of itself, or work in ways unrelated to it. It's a bit like a seduction. Once we are rehearsing, what
I look to most perhaps is rhythm and the quality of what it is the actors are seeing. I tend to think if it is not working rhythmically, if the actors' imaginations are no relating to the play with sufficient depth, then it is not working. But there are no rules.

Q: The constellation around the theatre director (text, writer, actors, public)

A: The audience is something I'm thinking about more, what exactly it is they bring to the theatre contract, how to be more specific in relating the work to them and the part they play in the contract - what they bring to the theatre - and I'm more determined to look for ways to sabotage that relationship if only to shock the event into some new haul of insight. Text is something towards which I have two opposing and conflicting impulses, one is my abiding sense that you have always to discover the performance in the text and another is that the text can't be the one dictating the decisions for the production. The actors are my most important collaborators while the relationship with the writer is the most challenging and often the most rewarding.

Q: The Druid Theatre Company was established in 1975 in Galway and was the first professional theatre company in Ireland outside Dublin. What makes the Druid special/different within Ireland's present theatrical panorama? (*one female directors in its history: Garry Hynes 197591 \& 1995 to date; Maeliosa Stafford [male] 1991-94).

A: Druid has a commitment to meeting its audience in three domains, in Galway, on tour throughout Ireland and on tour internationally and no one in Ireland meets that commitment to the degree that Druid does. Sometimes I feel that Druid is relied on to show the country to itself more than any other theatre company, more than the Abbey at times. It certainly is committed to programming work speaking to the Irish experience, and it also keeps in view whether that experience can translate across cultures. Druid consequently reaches a wider spread of audiences than any other company here. Also by virtue of creating work in Galway and away from a metropolitan centre it seems better enabled to take risk and has been the one company to take on large-scale epic projects, as in the Leenane Trilogy and 
DruidSynge, and to tour with it.

\section{Q: The company's name: Druid. Why?}

A: It is named after a character in the Asterix comics, the one who creates all the magic.

\section{Q: The company's guru playwrights?}

A: Druid has had key relationships with remarkable writers during each of its different phases, Tom Murphy in the 80s, Martin McDonagh in the 90s and currently Enda Walsh. But whilst the relationship has been crucial to both sides I couldn't say any of them has been a guru. It is more complex than that.

Q: Tell us about the company's general and particular commitments with theatremaking, with Galway city in particular, and with Ireland/Irish society in general.

A: Galway comes first and all the work rehearses and opens in Galway. If we look to the Antaeus myth, the monster whom Hercules takes on and who regains his strength from every time he touches the ground, then Galway is the earth from which Druid, as Antaeus, draws strength. On a practical level, it is good to develop work outside a major metropolitan centre, it allows for more focus. Druid also believes that the work it produces should succeed before any audience and takes all its work out on the road and on tour internationally.

\section{Q: How does the Druid theatre company} work?

A: Druid has a regular design team, an ensemble of actors, a regular team of technicians and crew and a small team of administration staff, and these are the people time and again who pull it off.

\section{Q: And the touring policy of the Druid?}

A: Touring funding needs to come from other than revenue funding, so Druid must find the money for touring each production separately and separate to its core work, something that is very time-consuming. International touring is impossible without Culture Ireland funding. CI is the organisation enabled to resource an international dimension to Irish art. After that, central national art agencies and international producers make up the gap. National touring is a thorny subject and in the absence of a central fund, regional partnerships between venues and companies have tried to step into the breach.
Currently in this vein is the NASC touring network. NASC is a partnership between seven venues to pool resources in order to enable touring with which Druid has a good relationship with seven venues that provide a touring network across all parts of Ireland.

Q: At the Druid, do you get many scripts? What assessment criteria do you follow on reception of a script? How did Tom Murphy, Enda Walsh and Martin McDonagh, for instance, got premièred at the Druid?

A: Druid accepts any play for assessment by the reading panel and this we call the open submissions programme. This is where Martin McDonagh and many others were discovered. Druid also commissions new work from writers, Enda Walsh's play The Walworth Farce came from such a commission. When the circumstances permit, Druid invites a writer to be writer-in-residence and such was the relationship with Tom Murphy when he wrote three new plays for Druid to produce in the 80s. We've invited writers to allow us consider their work for production and this has been successful in quite a few cases, including Lucy Caldwell's Leaves. We resource writers to research a play in a specific area that interests us and this can frequently lead to a commission; we have one such commission on the go at present. Again, there are no hard and fast rules.

Q: I would like you to put a few thoughts about theatre's relationship with academia and media in Ireland. How would you define it?

A: I would say the relationship is fraught. We don't have consistently informed or interesting critics in the press. And national television is slow to acknowledge events in the arts with only one review programme a week. However radio coverage on the arts is exceptional, beginning with a magazine programme, the Arts Show, being fronted by a playwright [currently Vincent Woods] who remains sensitive to how artists see things, regular slots for radio plays and a show dedicated to theatre. Academia I would suggest is very much wedded to a literary theatre to a degree that inhibits the development of other forms of theatre here. Ireland's is a writers' theatre and many vested interests keep it that way, although it is beginning to change. I would 
think academia gets the better end of the deal all told. Also, unlike elsewhere, it does seem that a career as an academic is incompatible with working in the theatre here. However the relationship can often be mutually productive and academics have shown great generosity towards Druid in many ways throughout its history.

\section{Q: And the theatre-going/consuming public in Ireland at the moment?}

A: Audiences aren't as strong as we need them to be in Ireland. Neither do the companies here do enough towards generating creative ways of gaining audience investment in the work we do. Largely we approach an audience as an undifferentiated patron with no specific background or equipment, indeed with little else than a desire to be entertained and enlightened, and I would say that this is altogether a naïve approach. But the empirical research isn't there yet to say just how many exactly are going to the theatre in Ireland, indeed who, from what economic background and from what address, and while a beginning has been made on such audience research, it is slow in coming.

\section{Q: Theatre Festivals in Ireland. Are they all packed in Dublin?}

A: Festivals start in early summer and continue back to back through until mid-autumn, largely without competing in terms of dates but this is not owing to a central calendar so much as an ad hoc filling in of the spaces - you can begin with Cork Midsummer's Festival in June, the We Are Here festival of avant garde work in Dublin in July, then Galway Arts Festival in July, Kilkenny Arts Festival in August, the Dublin Fringe in September, and Dublin Theatre Festival in late September/October.
This just lists the larger festivals but nearly every major town hosts an arts festival and Dublin certainly doesn't have a monopoly.

Q: Which production(s) at this year's festivals has/have particularly appealed to you and why?

A: Belarus Free Theatre featuring at Kilkenny Arts Festival this year has stayed with me. Work that is created in a situation of dictatorship, it doesn't so much choose to be political as simply understands itself to be political through and through. An eye-opener on many levels, not least the heart. I saw the Elevator Repair Service twice this year, and both Gatz and The Sound and the Fury rewrote the rules for me.

Thanks for your time, your enlightening and pleasant chat, Thomas.

Dublin 08.10.2008

Rosana Herrero-Martín holds a Ph.D. in Irish Theatre (University of Salamanca), a M.A. in Anglo-Irish Literature and Drama (University College Dublin), and a B.A. in English and German Philology (University of Salamanca). She has written the book The Doing of Telling on the Irish Stage: A Study of Language Performativity in Modern and Contemporary Irish Theatre (Frankfurt: Peter Lang, 2008). She is currently freelance Spanish lecturer (Instituto Cervantes, University of Bremen, University of Oldenburg) and literary translator living in Bremen, Germany. Her main areas of interest are theatre, post-colonial literature, literary translation, bilingualism and migration. 